\title{
PATHOGENESIS, HISTOLOGY, AND HORMONAL DEPENDENCY OF RAT MAMMARY NEOPLASMS INDUCED BY ORAL ADMINISTRATION OF HYDRAZINE-NITROFURAN ANALOGS
}

\section{Erdoğan Ertürk ${ }^{1}$}

\author{
Don B.Headley²
}

George T.Bryan ${ }^{3}$

Hydrazine-Nitrofuran türevlerinin ağız yolu ile verilnıesi sonı sıçanlarda meydana getirilen meme tümörlerinin patojenik gelişini, histolojisi ve hormonal bał̧̆mlılı̆ı

Özet: Simetrik veya asimetrik hidrazin türevlerinin çeşitli rodentlerde kolon, akciğerler ve karaciğer dahil, birçok organda kanserojen olduklarinin ortaya konmasindan sonra; buna karsinojen nitrofuran veya amino analoglarınin eklenmesiyle ne gibi bir değişme olacağı araştırlmıştır. Değişik bir tümör türü olarak, sıçanda meme kanserlerinin meydana getirilmesi; bu tümörlerin oluşumunda başka faktörlerin etkili olabileceğini düsündürmüs ve hormonlarla ilişkileri üzerinde durulmustur. Bu amaçla koruyucu, ya da sağıtıct etkisi umulan yumurtalıklarm sıkarılması operasyonuna başvurulmuştur. Ayrıca, yumurtalıkları alınan bir kısım sişana östrojenin distan verilmesi somu, ortadan kaldirtan bu etkinin sonradan sağlanıp sağlanamıyacă̆ı da araştırılmışıtr.

Karsinojen olarak kullanian, 2-hidrazino-4-(4-aminofenil)-tiyazol (APT) madáesi, stşanların yemlerine ağırlık itibariyle \% 0.01 oranında katılarak verildikte deney hayvanlarınm \% 68 inde $(34 / 50)$ meme tümörü meydana getirmistir. Onuncu haftadan itibaren büyümeye başlayan tümörlerin \% 48'i (14/29) süt bezi veya kanalmu dösseyen epitelden köken alnus adenokarsinom, arta kalan 15 tanesi $(\% 52)$ ise fibroadenom yapısı göstermistir. Diğer bir grupta, 50 siçanin 29 tanesinde oluşturulan meme tümörleri gelişmeye birakllmışır. Bunlar arasında 18 olayda, faplarınin $2 \mathrm{~cm}$ yi geçmesinden sonra ooforektomi operasyonu yapılmuştr.

1 Prof. Dr. U.Ü. Veteriner Fakültesi Patoloịi Anabilim Dalı, Bursa-Turkey

2 Araş. Gör. Department of Human Oncology, Clinical Science Center, University of Wisconsin, Medical School, 600 Highland Ave. Madison, WI. 53792 U.S.A.

3 Prof. Dr. Department of Human Oncology. Clinical Science Center, University of Wisconsin, Medical School, 600 Highland Ave. Madison WI. 53792 U.S.A. 
Bu sıçanlarda hormonal kontrolün ortadan kaldırlmasına rağmen sağıtıcı bir etki sağlanamadıŏ̀ bu siçanlarda tümör küçülmesi veya dökülüp regresyona uğraması gibi bir değişim görülmemekle anlaşılmıştır. Bir başka grupta ise (Gr.3), 44 sıçanin 24 ünde oluşan meme tümörleri 7 sıçanda gelişip çapları 2 cm'yi geçmiştir. Bunlarda uygulanan endokrin ablasyonu, poliöstradiolfosfat (PEP-estron) un $2 \mathrm{mg} / \mathrm{kg}$ orantnda verilmesiyle giderilmeye ve hormonal etkinin geri getirilmesine falişlmiş ancak tümörlerde bir regresyon şekillenmeniştir. Bu sonuçlar ooforektominin sağıtıcı bir etki yapamadı̆̆ını açıkca göstermistir. Diğer taraftan, profilaktik amaçla yapılan ooforektominin tümörlerin meydana getiriliş süresinde, büyüme ve malignitelerinde, bir sıçanda gelişen tümör sayılarında azalmalar meydana gelmiştir. Diğer bir grup sıçanlarda PEP enjeksiyonlar (östrojen) neticesi kanserojenin etkisinin tekrar yerine geldiği ve tümörlerin sayl ve malignitelerinde artışlar olduğu ortaya çımıstır. Bu sonuc, koruyucu ooforektomi ile risk altındaki kimselerde, meme kanserinin önlenebileceğini işaret etmektedir.

Summary: Hydrazines, either symmetrically or asymmetrically substituted with active moieties are well known rodent carcinogens, inducing neoplasms in colon, lungs and liver. Nitrofurans are also known chemical carcinogens, inducing variety of tumors in rodents, and many other experimental animals. In this study, the analog of nitrofuran carcinogens, aminophenyl-thiazole derivative of hydrazine (APT) was tested for its carcinogenicity, and the effects of estrogens on the induction of mammary tumors in rats.

The results showed that $A P T$ is a strong chemical rat mammary carcinogen, inducing high incidence of adenocarcinomas, that are strongly estrogen dependent, since the oophorectomy performed prior to carcinogen administration prevented the induction of mammary adenocarcinoma; and had no effect if, applied after the induced adenocarcinomas grew up to a size of $2.0 \mathrm{~cm}$ in diameter. However, if polyestrodiaphosphate (PEP) is given s.c. to prophylactically ablated rats, the full strength of APT carcinogenicity was returned.

\section{Introduction}

Hydrazine as in salted form $(3,13,30)$, as alkylated symmetrically $(5,17,18,24,28,29)$, or asymmetrically $(25,29,32)$, and in the hydrazide form of some organic acids like maleic (29), or formic acid $(4,6-10,16 ; 32)$, or even in some other more complex structures $(15$, 
31) has been reported to be carcinogenic when administered in the food or drinking water, or even by s.c., injections to the rats and mice of several strains of both sexes at any age. Hydrazines were first described organotropic carcinogens inducing adenoma and adenocarcinoma arising in the epithelial lining of large bowel of rats $(5,22,23)$. But, the later reports revealed that hydrazine derivatives were equally carcinogenic for lungs $(3,25,32)$, liver $(30)$, and many other organs $(28,31,32)$ if suitable dose is provided. On the other hand, hydrazines are found in some natural food plants like edible mushrooms (31, 32 ), and in the environment as the results of their long time use as herbicides (29) or jet probpellant and rocket fuels $(12,28)$.

During the course of our previous studies involving 5-nitrofuran compounds, some analogs, that may also be considered as the derivatives of hydrazine, were also found to exhibit carcinogenicity $(4,6-10$, 14-16). These were asymmetrically substituted and contained 5- nitrofuran nucleus in one side and acid or an alkyl radicals on the opposite end of the hydrazine. The carcinogenic potential was not equal for all these compounds as some asymmetrically substituted analogs were devoid of this character (16). Formylation $(15,16)$. methylation (9), or unsubstituted hydrazine $(9,16)$ conveyed the resulting carcinogens towards different organs or tissues that included gastro-intestinal tract, liver, pancreas, lungs, kidneys and adrenals, ovaries and uterus, and most interestingly the mammary glands and milk ducts' epithelial lining that were not previously reported as being seriously attacked by other hydrazine carcinogens $(4,7-9,15)$.

Induced mammary tumors included fibromas, fibroadenomas and all structural variation of glandular or ductal adenomas and adenocarcinomas that were s.c., transplantable and probably somewhat hormone dependent (15), similar to those observed in some other organs (34), and since the deacylation can occur (33). Among those tested hydrazine-nitofuran compounds, the alkylated analog (9) exhibited the highest carcinogenic activity for the breast tissues, and this may be due to the additional power furnished by alkylation that compares with little (15) or no activity of similar analogs (16) that had the hydrazine buried deep into the chemical structure.

The existence of fibroadenomas with varied amounts of epithelial and stromal elements, the increasing rate of histologic malignancy reflected by increasingly prominent anaplastic nature of secondary or 
further generations of transplanted tumors grown in the recipient rats, and the observation of some dependence of viability of these transplanted tumors on the sex of the recipient (15) all suggested the possible hormonal dependency of these mammary neoplasms $(15,34)$. like those induced by different chemical carcinogens (26).

APT induced a very high mammary tumor incidence with the shortest required latency period (9), and it was selected as the hydrazine containing carcinogenic chemical to study the pathogenesis, clinical and histological behaviour, and the hormonal dependency of mammary neoplasms that would be reflected by their maintenance and growth rate variations stimulated by endogenous or supplemented estrogens, and this paper reports these observations.

\section{Materials and Methods}

A total of 340 female weanling Sprague-Dawley rats (SpragueDawley, Madison, WI.) were randomly allocated into 10 groups, and were fed ad libitum either unmedicated control diet of Wayne Lab Blox (Allied Mills Inc., Chicago III.) or the same diet with $0.01 \%$ $(\mathrm{w} / \mathrm{w})$ APT for 66 weeks, followed by unmedicated control diet until the experiments ended (Table 1). Other treatments included ovariectomy prior to the experiments start (groups 5 through 10) or after the development and growth of mammary tumors larger than $2.0 \mathrm{~cm}$ in diameter (groups 3 and 4); and estrogen replacement therapy for either the whole experimental period (groups 7 and 8) or shorter durations (groups 9 and 10). Ovariectomies were performed under the ether anesthesia, by making bilateral incisions in both flanks to ligate, and excise the ovaries. Completness of ovariectomies was confirmed by vaginal smears taken for 5 days post surgery and those rats showing estrous on the last three days were removed from the study. These vaginal smears were continued at monthly intervals throughout the entire treatment period. Completness was also confirmed at the time of necropsy. Estrogen replacement therapy consisted of injections of every 14 days of polyestradiol phosphate ((PEP) Estradurin, Ayerst) at a dose of $2 \mathrm{mg} / 100 \mathrm{~g}$ body weight in $0.2 \mathrm{ml}$ of sodium phosphatenicotinamide buffer. All rats received prophylactic i.m., injections of $0.1 \mathrm{ml}$ of Benzathine penicillin G (Wyeth) every 10 weeks. Experimental animals were palpated weekly for developing tumors starting on the 10 th week of APT feeding since the first rat mammary tumor a previous study appeared at this time (9). The tumor growth was mo- 


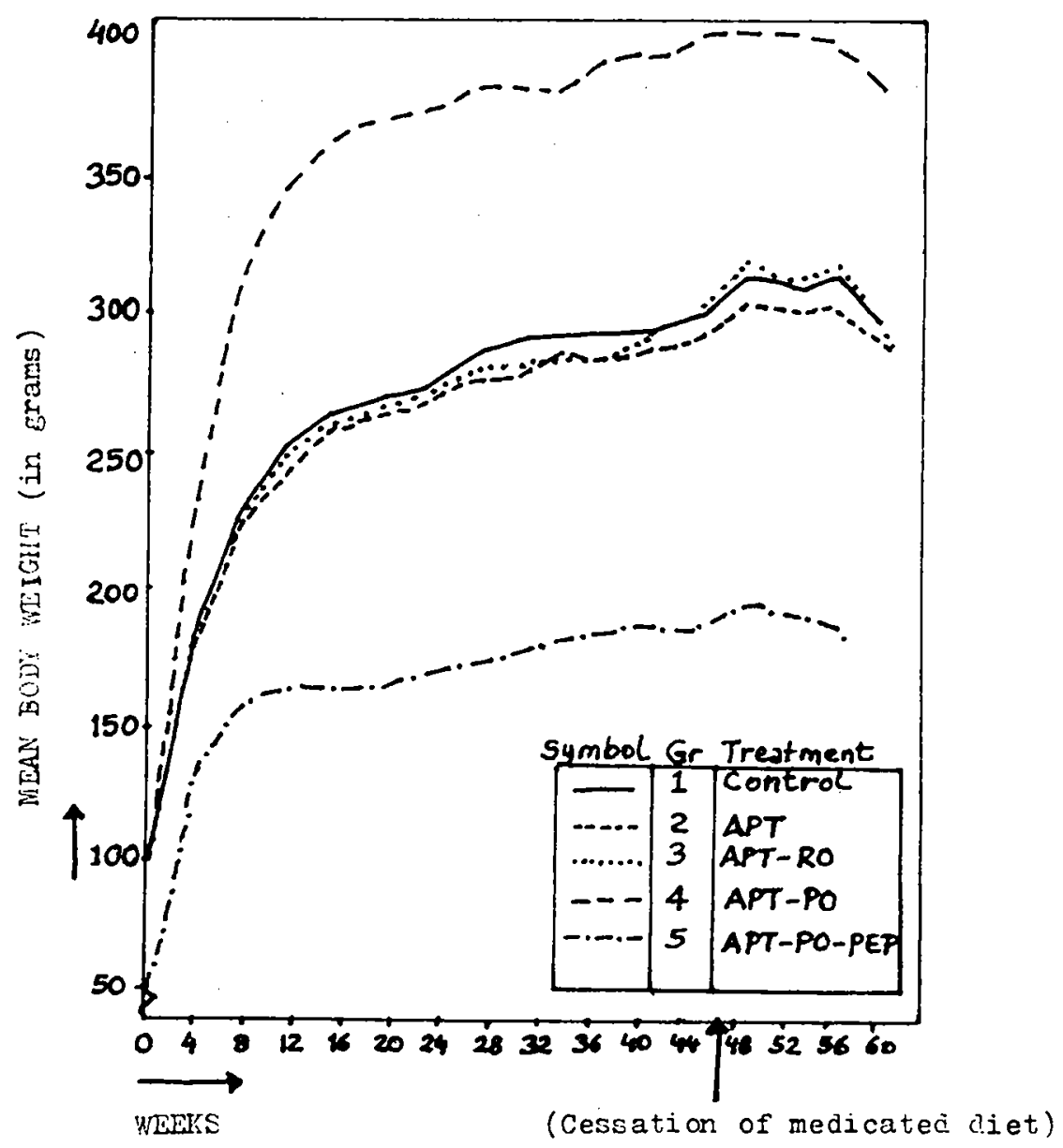

Chart. Growth curves for treatment and control rats. Detailed descriptions of treatments for the rat groups are found in table 1 . Rats were weighed every 4 weeks and the mean weights of all surviving rats are recorded. Mean weights of rats in groups 4 and 5 remained very similar to those of rats in groups 3 and 6 , respectively. The mean weights of groups 8,9 , and 10 rats were within $10 \%$ of the mean weights of group 7 rats. All rats receiving APT were placed on unmedicated diets after 46 weeks. Estrogen treatments were caesed at weeks 20 and 18 for groups 9 and 10 , respectively.

nitored by taking weekly measurements with calipers along the two perpendicular exes, one of which was always the longest dimention of the neoplasm. Animals were weighed and food consumptions were estimated every four weeks. Rats dying during or killed at the end were necropsied and the representative tissue or tumor samples were prepared for light microsropy as described earlier (9). 


\section{Results}

Although the survival times were similar, the growth rates varied (Chart) among the groups depending upon the additional therapies that included ovariectomy prior to or after the start of APT administration, and short or long time hormon supplementation (Table 1). Despite its high toxicity observed in a previous study (9), APT at this dosage did not cause any severe growth retardation. Remedial endocrine ablation seemed to have no effect on either the food comsumption or the growth rate of rats, if achieved by bilateral removal of ovaries

Table 1 Treatment Groups

\begin{tabular}{|c|c|c|c|c|}
\hline $\begin{array}{l}\text { Group } \\
\text { No: }\end{array}$ & $\begin{array}{l}\text { Rats with tu- } \\
\text { mor / survivors } \\
\text { Evaluated his- } \\
\text { tologically }\end{array}$ & $\begin{array}{l}\text { Number } \\
\text { of rats at } \\
\text { start }\end{array}$ & $\begin{array}{c}\text { Remedial } \\
\text { ovariectomy }\end{array}$ & Treatment \\
\hline 1 & $9 / 29$ & 30 & \multirow{9}{*}{$\begin{array}{r}18 / 29 \\
7 / 24\end{array}$} & \multirow{9}{*}{$\begin{array}{l}\text { Fed control diet }{ }^{\mathrm{a}} \\
\text { Fed APT } \\
\text { Fed APT }+ \text { remedial oopho- } \\
\text { rectomyc } \\
\text { Fed APT }+ \text { remedial oopho- } \\
\text { rectomy }+ \text { estrone } \\
\text { Fed control diet }+ \text { prophylac- } \\
\text { tic oophorectomyc } \\
\text { Fed APT }+ \text { prophylactic oop- } \\
\text { horectomy } \\
\text { Fed APT }+ \text { prophylactic oop- } \\
\text { horectomy +estrone } \\
\text { Fed APT }+ \text { prophylactic oop- } \\
\text { horectomy }+ \text { estrone }(20 \text { wks }) \\
\text { f } \\
\text { Fed control diet }+ \text { prophy- } \\
\text { lactic oophorectomy }+ \text { est- } \\
\text { rone } \\
\text { Fed Control diet }+ \text { prophy- } \\
\text { lactic oophorectomy }+ \text { est- } \\
\text { rone (18 wk) }\end{array}$} \\
\hline 3 & $29 / 50$ & 50 & & \\
\hline 4 & $24 / 44$ & 50 & & \\
\hline 5 & $3 / 28$ & 30 & & \\
\hline 6 & $3 / 50$ & 50 & & \\
\hline 7 & $21 / 33$ & 35 & & \\
\hline 8 & $5 / 15$ & 15 & & \\
\hline 9 & $7 / 13$ & 15 & & \\
\hline 10 & $6 / 14$ & 15 & & \\
\hline
\end{tabular}

a) Control diet consisted of Wayne Lab Blox and water ad libitum.

b) 2-Hydrazino -4- (4- aminophenyl) thiazole (APT) was fed ad libitum at a dose of 0.10 $\%(w / w)$ in ground Wayne Lab Blox for 46 weeks. Thereafter the rats were fed ummedicated control dict.

c) Remedial bilateral oophorectomy (RO) was performed when the rat had a mammary tumor diameter of $2 \mathrm{~cm}$.

d) Estrone in the form of Polyestradiol phosphate was given as biweekly S.c. injections at a dose of $20 \mathrm{mg} / \mathrm{kg}$ beginning on the day of oophorectomy and extending throughout the length of the experiment unless indicated otherwise (see groups 9 and 10).

e) Prophylactic bilateral oophorectomy (PO) was performed 6 days prior to feeding of APT diet or, for control rats, unmedicated diet.

f) Groups 9,10: had estrone therapy terminated after weeks 20,18 resp. 
after the induced tumors grew up $2.0 \mathrm{~cm}$ in diameter size. However, prophylactic bilateral ovariectomy (prophylactic endocrin ablation), performed 6 days prior APT medication did have a remarkable positive effect on the growth of female Sprague-Dawley rats since they grew as big as a male animal. On the other hand, the observation of the slowest growth rate for rats similarly treated but received additional PEP therapy to replace the delated endogenous estradiols, was also somewhat unexpected. This effect may be the result of excessive and continuous supplementation of sex hormones to compensate the preablated endogenous estrogens. The duration of PEP administration was important and this was evidenced by varied tumor incidences in groups 8 and 10 (Table 2).

Negative control rats (Group 1) (Tables 1,2) spontaneously developed one mammary adenocarcinoma, six mammary fibroadenomas and two subcutan fibrosarcomas occurring after a long latent period $(53 \pm 16$ weeks). This compares with the statistically highly significant mammary tumor indicence $(34 / 50)$ resulting from the carcinogen APT medication in group 2. The required latent period was 10 weeks that was much shorter than controls. Of these 29 breast tumors, 14 were adenocarcinomas of glandular or ductal origin; and 15 were fibroadenomas of mostly ductal origin and consisted of varied amounts of stromal connective tissue elements, also participated into the neoplastic formation. Mammary adenocarcinomas if orijinated from glandular or alveolar epithelium exclusively, contained very little or almost undetectable amount of stromal connective tissue, but, exhibited several forms of anaplasia, mostly medullary adenocarcinomas demonstrated 5-15 mitotic figures per high power field. The histological appearances varied from fibroadenocarcinoma, cystic and papillary, medullary, and cribriform architecture with different cell types that included glandular, fusiform, squamous, mucous producing metaplastic epithelium. Ductal adenocarcinomas usually contained more connective tissue than alveolar carcinomas in even the neighboring areas of the same nodule. The histological malignancy were in agreement with the multiplicity of nodules, and the higher the number of induced nodules the higher the grade of histologic malignancy was observed. One rat had up to 16 nodules of which some were most malignant as some others were benign fibroadenomas. Mammary neoplasms arising from the ductal epithelium developed into one cell lined simple fibroadenoma with excessive connective tissue, also called simple intra- 
Table 2

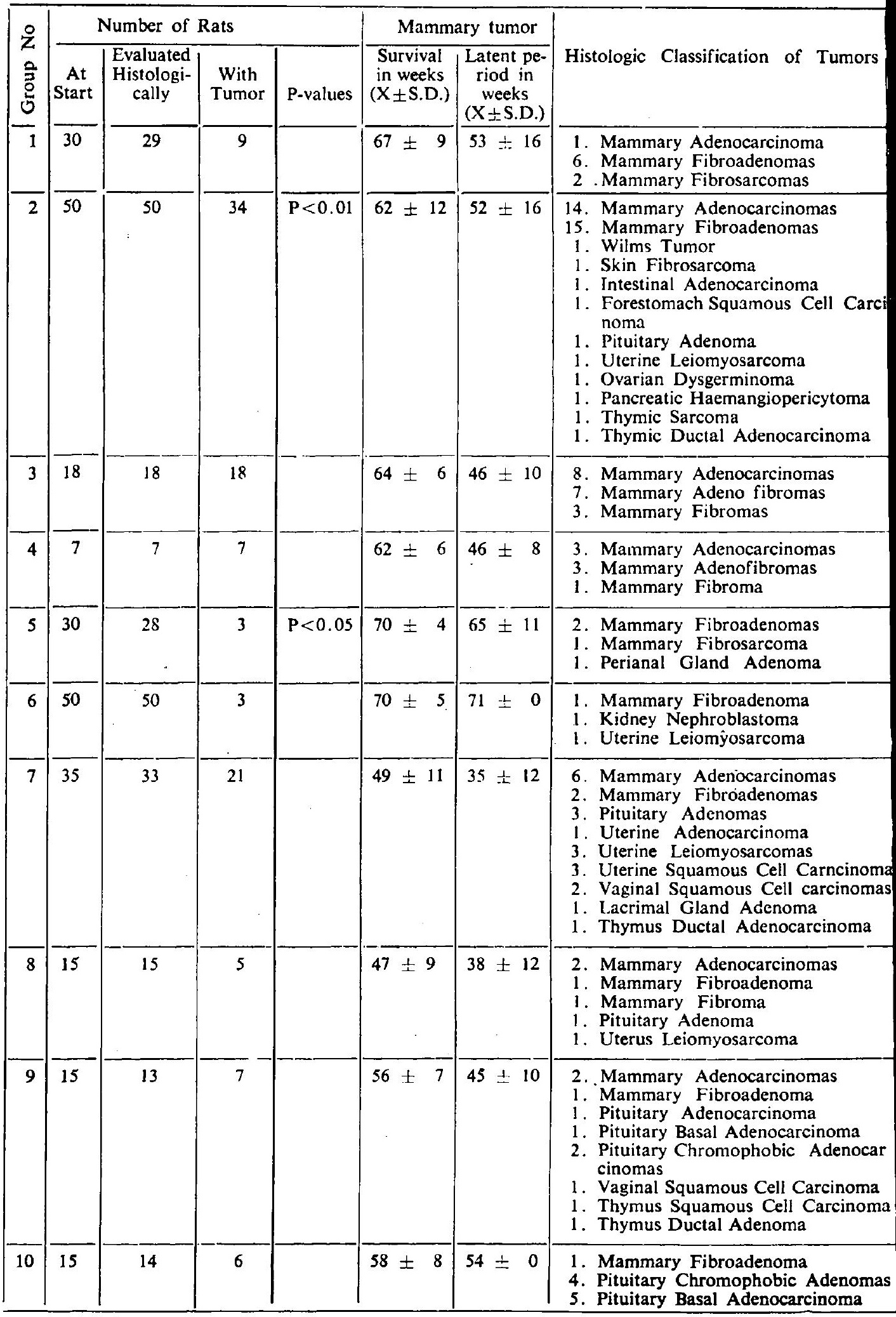


canalicular fibroadenoma, or with papillary projections into the milk duct that is similar to ductal papilloma with an abundant stroma surrounding these proliferations, or without a limiting basement membrane or connective stromal wall around to prevent the invasion of surrounding stroma which is seen in ductal fibroadenocarcinomas or adenocarcinomas. In a few cases, both the epithelial parenchymal cells and the fibroblastic stromal cells exhibited severe anaplasia and marked mitotic activity index to be classified as carcinosarcomas. Interestingly, the ductal tumors with lesser epithelial elements were more likely benign fibroadenomas even close to a fibroma, contrary to glandular tumors that did always exhibit a malignant histology, as no benign adenoma was detected in this series.

The remaining 10 induced neoplasms were of different origin arising from gastrointestinal, genito-urinary, and endocrin or exocrin glandular epithelium with a highly statistical importance $(p>0.01)$ (Table 3). The induction of genito-urinary and endocrin or exocrin neoplasms by APT indicates the relationships between its carcinogenicity and the production of a hormonal imbalance in the medicated female rats body.

In group 3, twenty-nine of 50 rats $(58 \%)$ developed mammary neoplasms, and 18 of these grew up $2.0 \mathrm{~cm}$ in diameter size for remedial endocrin ablation; and none of these eighteen ovariectomized rats demonstrated any change of size or color and consistency indicating the regression due to the removal of sex hormones (Tables 1.2). In the next group that had 24 mammary tumor cases in 44 evaluated rats, only seven animals were ovariectomized after the tumors reached the required size. These seven rats received PEP injections to recover

Table 3. $\mathrm{X}^{2}$ Values for Mammary Tumor Incidence by Group (a)

\begin{tabular}{|c|c|c|c|c|c|c|c|c|c|c|}
\hline Group & 1 & 2 & 3 & 4 & 5 & 6 & 7 & 8 & 9 & 10 \\
\hline 1 & & 10.1 & & & 3.5 & 8.9 & & & & \\
2 & & & & & 23.6 & 41.2 & 0.17 & 0.91 & & \\
3 & & & & & & 0.56 & & & & \\
4 & & & & & & & & & & \\
5 & & & & & & & & & & \\
6 & & & & & & & & 1.4 & 6.25 & \\
7 & & & & & & & & & & 0.33 \\
8 & & & & & & & & & & 0.28 \\
9 & & & & & & & & & \\
\hline
\end{tabular}

(a) $\mathrm{X}^{2}>3.84$ is significant $(\mathrm{p}<0.05) . \mathrm{X}^{2}>6.63$ is highly significant $(\mathrm{p}<0.01)$. 
from created hormonal imbalance, also exhibited no tumor regression, as the result of hormon supplementation. These results indicate that, the remedial endocrin ablation has no useful effect to regress the already developed or chemically induced mammary neoplasms in the rat.

Prophylactic ovariectomy, on the other hand, had profund effects in the induction, the growth characteristics, multiplicity, and on the grade of malignancy of either spontaneously developing (in group 5) or APT-induced (in group 6) mammary tumors. In group 5, three of 28 evaluated rats developed tumors, of which 2 were late occurring mammary fibroadenomas that are known to be controlled by pituitary growth hormone (2), and one was subcutan fibrosarcoma (Table 2). In the test of prophylactic endocrin ablative approach in the treatment of mammary cancer, the group 6 gave us very important results confirming the effects of estradiols on the induction of mammary neoplasms. Contrary, the results obtained from groups 2 (much higher tumor incidence without ovariectomy), and 3 (no remedial action from ovariectomy performed after the induction of tumors), the statistically insignificant tumor incidence (even smaller than the controls value) was observed. This effective result was further strengthened by the increased tumor incidence in the seventh group after reestablisment of hormonal imbalance by PEP injections (Tables 1,2). Group seven rats had a statistically highly significant (21 out of 33 ) incidence of early occurring and mostly anaplastic adenocarcinomas of mammary or other genital organs and in some other glands. The duration of the estrogen supplementation was also important here, and this is seen in the resulting lower tumor incidence due to the shorter time of PEP injections in the group 8 ( 5 out of 15 rats had tumors). This hormonal dependency was further evidenced by the last two control groups $(9$, and 10) that were used to evaluate the compensation of the ablated estradiol activity, by exogenous supplementation of this hormone for the duration of APT-medication, or in a reasonably shorter term (66 wks vs 20 wks.). As the result, both groups had tumor incidences higher than the untreated controls. This favored the longer period of PEP administration (dose-time effect), since more and malignant tumors were observed in group 9 (Tables 1,2), and by the induction of endocrin gland tumors, especially pituitary neoplasms that are known to be closely related with ovarian hormones (2). 


\section{Discussion}

The molecular basis of the carcinogenicity of hydrazine nitrofuran derivatives is not known at this time. This group of compounds contain a hydrazine nucleus which is a well established carcinogen $(3,5,17,20,21,24,25,27,32)$, and either a 5-nitrofuryl or 5-nitrophenyl-thiazole, or else an amino form of these derivatives that constitute another carcinogenic portion $(6,10,14,16)$ in their chemical structure. The metabolism and biotransformation of 5-nitrofurylthiazoles involve the n-hydroxylation of 5-nitro moiety which may be carried out by several enzyme systems including nitroreductase, mixedfunction oxygenases (cytochromes, xanthine oxidase) and prostaglandin endoperoxide synthetase $(4,6,33)$. On the other hand, hydrazines have been reported to follow totally different pathways (1, $6,12,13,18,20-22,24,28)$ including nuclephylic-electrophylic substitutions by producing free radicals from their alkylated forms. However, 1, 1-dimethylhydrazine was found less carcinogenic than hydrazine sulfate or chloride (25) those have capability to ionize and produce a positively charged hydrazine that can attack to any biologically important macromolecule with nucleophylic character $(1,12$, 13, 18). Monomethylhydrazine was noncarcinogenic (25) compared with 1,1-dimethylhydrazine when they were tested in mice. This difference may be understood if they were considered as alkylating agents $(1,20)$. This concept fits equally well to the observation of the highest tumor incidence induced with the asymmetrically substituted nitrofuryl-thiazole hydrazines represented in our series by DMNT, a structure that has two methyl radicals on the hydrazine nucleus (16). There is a marked number evidence supporting the idea that substituted hydrazines are metabolized to active metabolites via deacylating enzymes present in most tissues (33) which is a corollary to the fact that hydrazines produce tumors in a large number of organs or tissues $(25,27,32)$. We reported the high incidence of mammary tumor production by hydrazine derivatives $(6-9,14-16)$ for the first time, except Severi and Biancifiori (27) who showed another hydrazide to induce mostly lung together with some breast tumors. Despite the fact, that hydrazines were kept responsible from the beginning, as to carcinogen for colon epithelium, this kind of neoplasms were not observed in our series (14-16). This difference may an indication of different available metabolic pathways for differently substituted hydrazines acted as carcinogens. 
The pathogenesis, and histological characteristics of mammary neoplasms induced by APT in this study were not different than those induced by other carcinogens including 5-nitrofurans (6-9, 14-16), salted $(3,13,30)$ or alkylated hydrazines $(5,17,18,20-29,32)$, or other chemicals (26). )The hormonal dependency of rat mammary tumors induced by APT was reflected by the lower incidences following the prophylactic ovariectomy performed in groups of rats with or without the supplementation of ablated endogenous estradiols. In a prophylactically ovariectomized group, APT administration did not result in a statistically significant tumor production, in fact, the number of tumors and the tumor bearing animals were lesser than those of controls: However, the PEP administration effectively corrected this tumor inhibition, provided sufficiently long time and suitable dose response. In some other control rats used to evaluate the effects of hormon alone, estradiol induced statistically significant tumor incidence, even without the administration of APT as the carcinogen. The remedial endocrine approach however, was not seem to be fruitful since no tumor regression was observed in rats ovariectomized after the induced tumors reached $2 \mathrm{~cm}$. in diameter size.

The growth rate of rats were significantly altered by the creation of hormonal imbalance by prophylactic ovariectomy, and this was seen in female rats growing as big as a male animal even despite the administration of toxic (16) and carcinogenic APT. The rats similarly treated but received additional estradiol supplementation appeared as the slowest growing, and reached the size of negative controls or groups without hormonal alteration. These results may help to understand why male rats naturally grew bigger than opposite sex, or females growing the ablation of ovaries. Hormonal imbalance may sometimes be the result of long term use of hormon-containing drugs, like contraceptives in everyday use, and may create some important

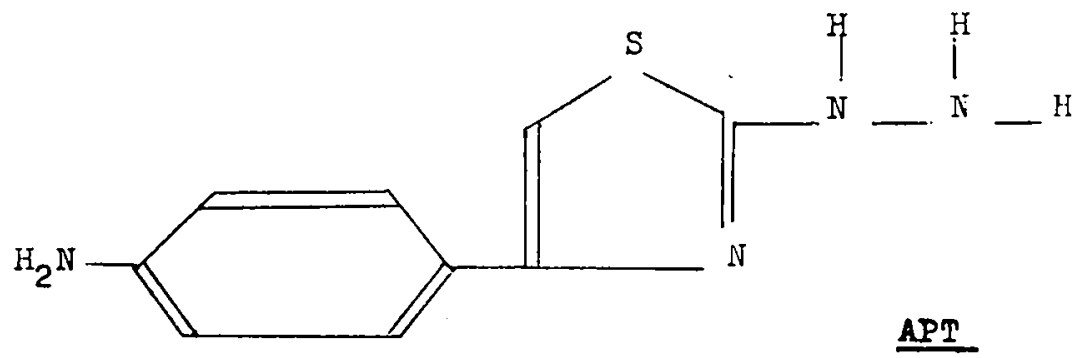

Text figure 1. 2-Hydrazino -4(4-aminophenyl) thiazole 
problems if it occurs simultaneously with some environmental factors that can act synergistically to enhance and make it strong enough to induce tumors of mammary, pituitary or any other gland or tissue origin.

\section{References}

1. Autrup, H., Schwartz, R.D., Essigmanu, J.M., Smith, L., Trump, B.F., and Harris, C.C. (1980): Metabolism of Aflatoxin-B 1, Benzo (a) pyrene, and 1, 2-Dimethylhydrazine by cultured rat and human colon., Teratogenesis, Carcinog. Mutagenesis $1: 3-13$,

2. Benirschke, K.. Garner, F.M., and Jones, T.C. (1978): Pathology of Laboratory Animals, Vol I. pp. 388, and Vol II. pp. 1209-1211 Springer-Verlag, New York N.Y.

3. Bhide, S.V., D'Souza, R.A., Sawa;, M.M., and Ranadive, K.J. (1976): Lung tumor incidence in mice treated with hvdrazine sulfate., Intl. J. Cancer, 18: 530-535.

4. Bryan, G.T. (1978): Carcinogenesis-A Comprahensive Survey,, Vol. 4: Nitrofurans., Raven Press New York. N.Y.

5. Carachi, R., Busuttl, A., Joffe, S.N., Blumgart, L.H. (1977): The protective role of dietary fibre in an experimental model for colorectal cancer., Brit. I. Surg., 64: 837.

6. Cohen, S.M., Alter, A., and Bryan, G.T. (1973): Distribution of radioactivity and metabolism of formic acid 2- (4-(5- nitro)2-fuyl) -2-thiazolyl) hydrazide following oral administration to rats and mice., Cancer Res., 33: $2802-2809$.

7. Cohen, S. M., and Bryan, G.T. (1973): Carcinogenesis caused by Nitrofuran derivatives., Proc. 5. th Intl. Cong. Pharm., San Francisco, 1972., Vol. 2. pp. 164-170, Karger; Basil.

8. Cohen, S.M., Ertürk, E., Bryan, G.T. (1970): Carcinogenicity of formic acid 2- (4(5-nitro-2- furyl) -2- thiazolyl) hydrazide in Siviss mice., Cancer Res., 30: 906-912.

9. Cohen, S.M., Ertürk, E., Price, J.M., and Bryan, G.T. (1970): Comparative carcinogenicity in the rat of 2- Hydrazinothiazoles witl nitrofuryl, nitrophenyl, and aminophenyl substituents in the 4-position., Cancer Res., 30: 897-901.

10. Croft, W.A., and Bryan, G.T. (1973): Production of urinary bladder carcinomas in male hamsters by N- (4-(5-nitro-2-furyl)- 2- thiazolyl) formamide, N- (4-(5-nitro-2-furyl) -2-thiazolyl) acetamide; or 5-ormic acid 2- (4-(5-nitro-2-furyl) -2-thiazolyl) hydrazide., J. Natl. Cancer Inst., 51: $941--949$.

11. Diczfalusy, E. (1954): Polyestradiolphosphate (PEP): A long acting water soluble estrogen., Endocrinology 54: 471-477.

12. Dost, F.N. (1979): Metabolism of hydrazine. ,Sci. Tech. Aerosp. Rep., 17: (No 22): 26,

13. D'Souza, R.A., Maru, G.B., and Bhide, S.V. (1976): Effect of hydrazine sulfate (HS) on nucleic acid biosynthesis and activities of nucleases in Swiss mice. Ind. J. Cancer, 13: 252-256. 
14. Ertürk, E., Cohen, S.M., and Bryan, G.T. (1970): Induction, hisfogenesis, and isotransplantability of renal tumors induced by formic acid 2- (4- (5-nitro-2- fury!') -2- thiazolyl)hydrazide in rats., Cancer Res., 30: 2098-2106.

15. Ertürk, E., Morris, J.E., Cohen, S.M., Price, J.M., and Bryan, G.T. (1970): Transplantable rat mammary tumors induced by 5- nitro-z-furaldehyde semicarba:one, and by formic acid 2- (4- (5- nitro-2- Furyl) -2-thiazolyl) hydrazide., Cancer Res., 30: 14091412.

16. Ertürk, E., Morris, J.E., Cohen, S.M., Von Esch, A.M., Crovetti. A.J., Price, J.M., and Bryan, G.T. (1971): Comparative carcinogenicity of formic acid 2- (4- (5- nitro-2furyl) -2- thiazolyl) hydrazide and related chemicals in the rat., J. Natl. Cancer Inst., 47: $437-445$.

17. Freeman, H.J., Spiller, G.A., and Kim. Y.S. (1978): A double-blind study on the effect of purified cellulose dietary fibre on 1,2-dimethylhydrazine induced rat colonic neoplasia Cancer Res., 38: 2912-2917.

18. Glauert,H.P., and Bennink, M.R. (1980): Metabolism of 1,2-dimethylhydrazine (DMH) by cultured rat colon epithelial cells., Fed. Proc., 39: 434, (abst. 882).

19. Kitay, J.I. (1963): Effects of estradiol on pituitary-adrenal function in male and feinale rats., Fndocrinology, 72: 947-954.

20. Kleinhues, P. (1979): On the mechanism of action of the carcinogen 1, 2-dimethylhydrazine., Zentralbit. Allg. Pathol., 123: 282.

21. La Mont, J.J., O'Gorman, T.A. (1978): Experimental colon cancer., Gastroenterology 75: $1157-1169$.

22. Mak, K.M., Slater, G.I., Hoff, M.B. (1979): Inhibition of DNA synthesis by carcinogens in human colon mucosa in organ culture., J. Natl. Cancer Inst., 63: 1305-1312.

23. Mehta, R.G., Fricks, G.M., and Moon, R.C. (1980): Androgen receptors in chemically induced colon carcinogenesis., Cancer 45: 1085-1089.

24. Reddy, B.S., and Hirota, N. (1979): Effect of dietary ascorbic acid on 1,2-dimethylhydrazine-induced colon cancer in rats., Fed. Proc., 38: 714 (Amst. 2565).

25. Roe, F.J.C., Grant, G.A., and Millican, D.M. (1967): Carcinogenicity of hydrazine and 1,1-dimethylhydrazine for mouse lung, Nature, 216:375-376.

26. Rose, D.P., Prmitt, B., Stauber, P., Ertürk. E., and Bryan, G.T. (1980): Influence of dosage schedule on the biological characteristics of $\mathrm{N}$-nitrosomethylurea-induced rat mammary tumors., Cancer Res., 40: 235-239.

: 27. Severi, L., and Bianciliori, C. (1968): Heparic carcinogenesis in CBA / cb / Se mice and $C b$; Se rats by isonicotinic acid hydrazide and hydrazine sulfate., I. Nat!. Cancer Inst., 41 : $331-340$.

28. Toth, B. (1980): Carcinogenesis by Gyrometrin of Gyrometra esculenta., Fed. Proc., 39: 884 (Abst. 3247).

29. Toth, B., and Nagel, D. (1979): Carcinogenesis by Edible Mushroom Hydrazines., Prcc. Am. Ass. Cancer Res., 20: 43 (Abst. 174). 
30. Turnsov, V.S. (1980): Morphology and histogenesis of anal region and clitoral gland tumors induced in mice by 1,2- dimetlylhydrazine., J. Natl. Cancer Inst., 64: 1161 1167.

31. Shank, H.C. (1980): Comparative metabolism of propellant hydrazines., Natl. Tech. Inf. Service, Springfield VA, as AD A074 634; 7: AMRL_-TR-79-57, s1 po.

32. Swietlinska, Z., and Zuk, J. (1978): Cytotoxic effects of Maleic hydrazide (MH), Mutat, Res. 55: 15-30.

33. Wang, C..Y., and Bryan, G.T. (1974): Deacylation of carcinogenic 5-nitrofuran derivatives by mammalian tissues., 9: 423-428.

34. Yoshida, O., Ertütk, E., Bryan, G.T. and Lowcr, G.M., Jr. (1973): The effect of gonadectomy and hormone administration on the urinary bladder carcinogenicity of $\mathrm{N}$ (4-(5-nitro-2-furyl) -2-thiazolyl) formamide in male and female Siviss mice., Invest. Urol., 11: 216-220. 